Egyptian Journal of Aquatic Biology \& Fisheries

Zoology Department, Faculty of Science,

Ain Shams University, Cairo, Egypt.

ISSN $1110-6131$

Vol. 24(7): 981 - 994 (2020)

www.ejabf.journals.ekb.eg

\title{
Proximate Composition and Trace Metals Concentrations in Macrobrachium vollenhovenii (Herklots, 1857) from Badagry Creek, Lagos, Nigeria
}

\author{
Abayomi A. Jimoh ${ }^{1, *}$, Abdulrafiu O. Majolagbe ${ }^{2}$, Gabriel O. Mekuleyi ${ }^{1}$, Edwin O. Clarke ${ }^{1}$, \\ Fatai G. Owodeinde ${ }^{1}$, Ayofe M. Hammed ${ }^{1}$, Prince E. Ndimele ${ }^{1}$ and Oluwaseun O. Adeniji ${ }^{1}$
}

1. Department of Fisheries, Lagos State University, Ojo, Lagos, Nigeria

2. Department of Chemistry, Lagos State University, Ojo, Lagos, Nigeria

*Corresponding Author: princeaajimoh@yahoo.com

\begin{abstract}
ARTICLE INFO Article History:

Received: Oct. 2, 2020

Accepted: Dec. 7, 2020

Online: Dec. 30, 2020

Keywords:

Badagry creek, Proximate composition, Trace metals, Macrobrachium vollenhovenii

\section{ABSTRACT}

The composition and approximate concentrations of three trace metals - iron (Fe), zinc ( $\mathrm{Zn})$ and magnesium (Mg) - of 160 samples of Macrobrachium vollenhovenii (African river prawn) from Badagry creek were investigated for four months across the rainy and dry seasons. Length and weight of the prawns varied from $15.0 \mathrm{~cm}-17.6 \mathrm{~cm}$ and $72.76 \mathrm{~g}-130.65 \mathrm{~g}$ respectively. The approximate analysis was performed in triplicates and the collected data were analyzed using analysis of variance and T-test. Mean values for protein were $52.18 \pm 1.11 \%$ (rain) and $43.13 \pm 1.13 \%$ (dry); lipids were $9.65 \pm 0.65 \%$ (rain) and $3.50 \pm 0.55 \%$ (dry); ash were $23.39 \pm 1.06 \%$ (rain) and $12.00 \pm 1.11 \%$ (dry); crude fibre were $9.15 \pm 0.42 \%$ (rain) and $9.35 \pm 6.08 \%$ (dry); moisture content were $4.08 \pm 0.44 \%$ (rain) and $31.25 \pm 5.23 \%$ (dry), and carbohydrate were $1.58 \pm 0.07 \%$ (rain) and $1.35 \pm 0.17 \%$ (dry). Protein, ash, moisture and lipids values at different seasons were significantly different ( $p$ $=0.05)$. The trace metal values of the species were within standard recommended range set by World Health Organization. The mean values for zinc $(\mathrm{Zn})$ were $5.10 \pm 0.64$ (rain) and 5.16 \pm 0.27 (dry) mg/100g; magnesium $(\mathrm{Mg})-20.00 \pm 1.02$ (rain) and $18.00 \pm 1.10$ (dry) $\mathrm{mg} / 100 \mathrm{~g}$ and iron $(\mathrm{Fe})-$ $3.03 \pm 0.40$ (rain) and $2.59 \pm 0.39$ (dry) $\mathrm{mg} / 100 \mathrm{~g}$. There was no significant difference of $\mathrm{Zn}$ and Fe contents between seasons $(\mathrm{p}=0.05)$, but the values for magnesium were significantly different $(\mathrm{p}=0.05)$. This study indicated that, Macrobrachium vollenhovenii, from Badagry creek could be very useful as an alternative source of high-quality protein, energy and mineral supply for human consumption and even for feed formulation for animals because they contain considerable amount of trace metals.
\end{abstract}

\section{INTRODUCTION}

Shellfishes play a significant role in providing good nutritional value, income, employment and foreign currencies for the countries. Also providing high quality minerals and nutrients for maintenance and growth of human body (Dong, 2001). The demand for shellfishe has increased in recent times as a result of the rapid increase in human population around the world. As a result of this increase in demand for shellfishes 
and the subsequent increase in production, it is important to constantly monitor their nutritional quality and one of the prominent ways of assessing the nutritional quality is via proximate composition analysis. The proximate composition provides useful information on the percentage of essential food constituents which include protein, lipids, carbohydrate, minerals and water. Hence, proximate body composition is a good indicator of physiological condition of an organism (Siva- Reddy et al., 2013). Nagabhushanam and Mane (1978) reported that the vital role of biochemical contents of food in physical growth, development and maintenance of normal body function cannot be over emphasized.

Prawns and shrimps are known to dwell on sediment which is a sink for metals in aquatic ecosystems (Kumolu-Johnson et al., 2010). Jimoh and Anetekhai (2004) reported that, during feeding, prawns and shrimps consume sand and mud along with detritus. Due to their wide range of distribution, shellfishes contain varying amounts of trace metals (Asuquo and Udoh, 2002) which, in this perspective, are essential and not toxic at low concentration. Macrobrachium vollenhovenii, is a widely-distributed prawn along the coast of West Africa, serve as a source of food and generate income to many West African's coast countries (Jimoh et al., 2019). The need to assess the nutritive quality of $M$. vollenhovenii from Badagry creek in terms of its proximate composition and trace metals has become essential since this prawn and associated species are a major source of food and economically important to the people living in and around the creek. To the best of our knowledge, the proximate composition and trace metals of $M$. vollenhovenii from Badagry creek has not been reported recently. Therefore, this study aimed to investigate the proximate composition of the carcass of Macrobrachium vollenhovenii from Badagry creek as well as examine the presence of trace metals in the species.

\section{MATERIALS AND METHODS}

\section{Sampling Area}

Samples of Macrobrachium vollenhovenii (African river prawn) were collected from fishmongers along the Badagry Creek. The Badagry Creek (Fig. 1) lies between latitudes $6^{\circ} 25^{\circ}$ and $6^{\circ} 30 \mathrm{~N}$ and longitude $3^{\circ} 0^{\prime}$ and $3^{\circ} 45 \mathrm{E}$ (Lawal-Are and Kusemiju, 2000) and opens into the Atlantic Ocean via the Lagos harbor. It is also a part of a continuous system of lagoons and creeks lying along the coast of Nigeria from the border with the Republic of Benin to Niger Delta, with the depth of water ranging from 1-3m (Ndimele and Jimoh, 2011).

\section{Sampling Procedure}

One hundred and sixty (160) samples of fresh Macrobrachium vollenhovenii (African river prawn) were collected over four months, which is from July - August (rainy season) and February - March (dry season) from Badagry creek. Freshwater prawn samples were purchased from fisher-folks who employed fish cages and woven cylindrical non-return valve traps for prawn capture. The gears were set overnight using coconut and fresh palm oil fruits as baits for the prawns. Selection of prawns was done 
randomly as they were harvested from the basket traps. Thereafter, prawns along with water samples were transported to the laboratory.

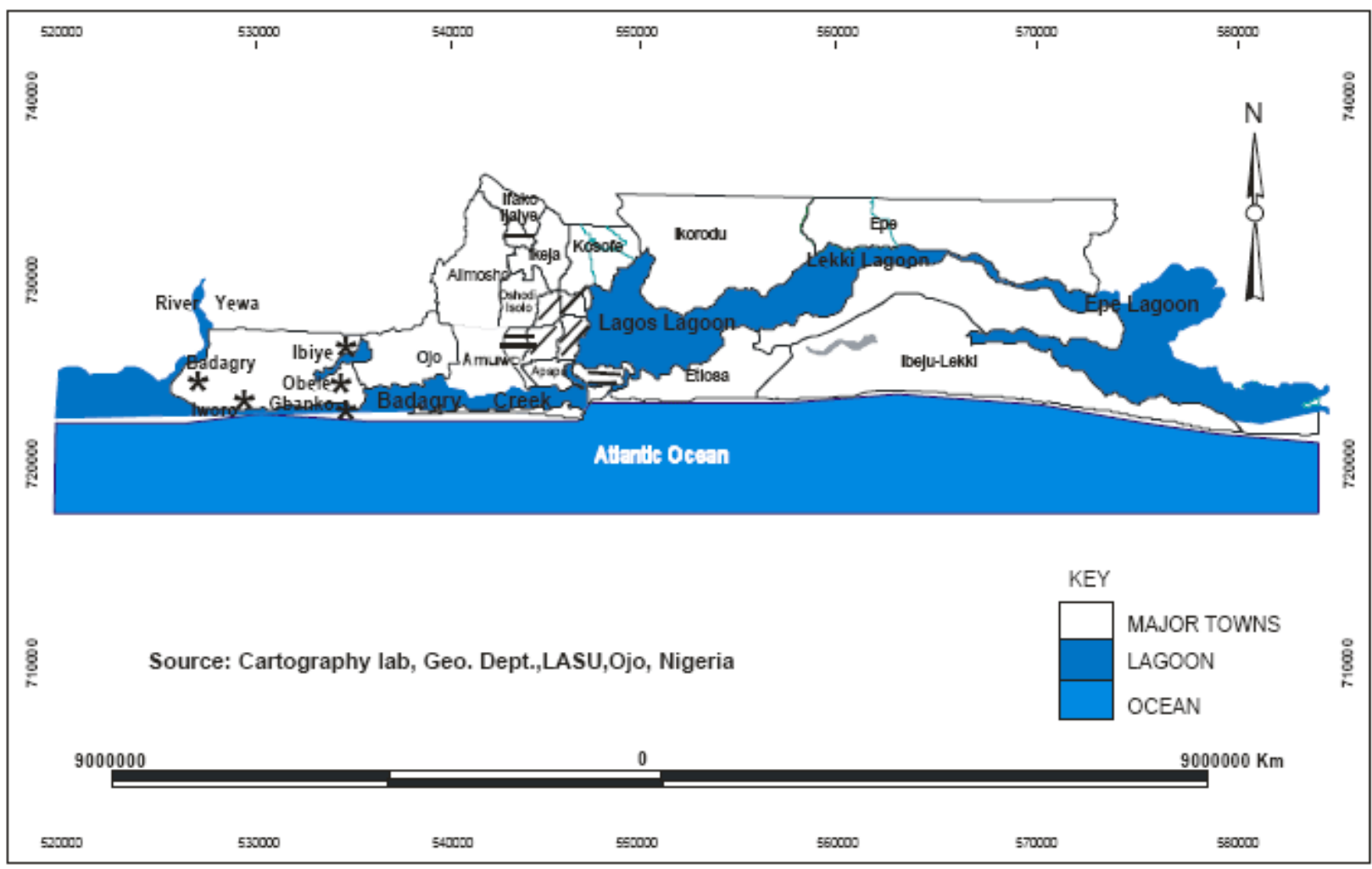

Fig. 1: A map showing Badagry Creek

Source: Cartography Laboratory, Geography Department, LASU, Ojo

\section{Laboratory Preparations}

In the laboratory, fresh prawns were washed in flow water to remove sticky dirt and were subsequently identified using Identification Guides (Powell, 1982). Routine body measurements such as total prawn length and body weight were determined using a $30 \mathrm{~cm}$ plastic ruler and a sensitive weighing balance (Mettler PM 400) and recorded to the nearest $0.1 \mathrm{~cm}$ and $0.01 \mathrm{~g}$ respectively. Prawn samples were oven dried at a temperature of $105^{\circ} \mathrm{C}$ for about 10 hours to constant weight and milled separately to powder using a porcelain mortar and pestle. The samples were stored in labeled plastic packs, sealed and sent for analysis, which was done in triplicates.

\section{Physico-Chemical Parameters}

Water samples were collected directly from each sampling station in $2 \mathrm{~L}$ plastic containers, which was washed inside-out with nitric acid to remove contaminants. Samples were stored immediately in a cooler, in order to ensure that the physical properties of the water samples were maintained, and transported to the laboratory for analysis. Temperature and $\mathrm{pH}$ were determined in situ using a mercury-in-glass thermometer; $\mathrm{pH}$ was measured using a pH meter Hanna 8198129 model while dissolved 
oxygen, salinity, total alkalinity and total hardness were determined by titration (Boyd, 1981).

\section{Proximate Analysis}

Proximate composition of the shellfish was determined by conventional method of Association of Official Analytical Chemists, AOAC (2000). Triplicate determinations were carried out on moisture content, lipids, crude protein, carbohydrates and ash content.

Estimation of Moisture: At first, the initial weights of the samples were taken. Then samples were dried in an oven (Memmet 854 Schwabach) at about $105^{\circ} \mathrm{C}$ for 10 hours until a constant weight was reached and cooled in a desiccator (Bel-art H420580001). The samples were then weighed again. Thereafter, the samples were minced in an electric grinder.

Percentage $(\%)$ of moisture $=($ Weight loss/Original weight of sample $) \times 100$

Estimation of Lipid: For the estimation of lipid content, the dried samples left after moisture determination were finely grounded and the fat was extracted using a non-polar solvent, ethyl ether. This was done by heating the sample in $40 \mathrm{ml}$ of Ethyl ether, and allowing to cool. After extraction, the solvent was evaporated and the extracted materials were weighed.

Percentage $(\%)$ of fat $=($ Weight of extract $/$ Weight of sample $) \times 100$

Estimation of Protein: The protein content of the fish was determined by micro-kjeldahl method. It involves conversion of organic nitrogen to ammonium sulphate by digestion with concentrated sulphuric acid in a micro-kjeldahl flask. The digest was diluted, made alkaline with sodium hydroxide and distilled. The liberated ammonia was collected in a boric acid solution and was determined via titration.

Percentage $(\%)$ of protein $=(c-b) \times 14 \times d \times 6.25 / a \times 1000 \times 100$

where

$\mathrm{a}=$ sample weight $(\mathrm{g})$

$b=$ volume of $\mathrm{NaOH}$ required for back titration and neutralize $25 \mathrm{ml}$ of $0.1 \mathrm{~N} \mathrm{H}_{2} \mathrm{SO}_{4}$ (for sample)

$c=$ volume of $\mathrm{NaOH}$ required for back titration and neutralize $25 \mathrm{ml}$ of $0.1 \mathrm{~N} \mathrm{H}_{2} \mathrm{SO}_{4}$ (for blank) $\mathrm{d}=$ normality of $\mathrm{NaOH}$ used for titration, $6.25=$ conversion factor of Nitrogen to protein

Estimation of Ash: The ash content of a sample is the residue left after ashing in a muffle furnace (Gerhardt) at about $55^{\circ}-60^{\circ} \mathrm{C}$ till the residue turned white.

Percentage $(\%)$ of ash $=($ Weight of ash $/$ Weight of Sample $) \times 100$ 
Estimation of Carbohydrates: $0.2 \mathrm{~g}$ of sample was homogenized with $10 \mathrm{ml}$ of $2.5 \%$ $\mathrm{H}_{2} \mathrm{SO}_{4}$.It was boiled for 20 minutes and allowed to cool, then filtered to get a filtrate of about $20 \mathrm{ml} .0 .1 \mathrm{ml}$ of diluted solution was diluted with $1 \mathrm{ml}$ of water, filtered with $0.1 \%$ anthrone. The mixture was boiled for ten minutes.

Carbohydrate content was calculated as follows: $100-($ Weight in grams [protein + fat + water + ash + alcohol] in $100 \mathrm{~g}$ of food).

Estimation of Crude Fibre: Percentage crude fibre was obtained by difference method. That is by subtracting the sum of total carbohydrate, total lipid content, total protein, ash content and moisture content. Blank is prepared with $1 \mathrm{ml}$ of water and $3 \mathrm{ml}$ of anthrone, and absorbance is read at $620 \mathrm{~nm}$.

Crude fibre $=100-$ Carbohydrate $\%+\operatorname{Lipid} \%+$ protein $\%+$ ash $\%+$ moisture $\%$

\section{Concentration of Trace Metals}

Prior to the determination of the concentration of trace metals in the samples, the nitric acid digestion technique (APHA, 1992) was used. Dry pulverized sample (1g) from each of the prawn samples was placed in a $100 \mathrm{ml}$ decomposing beaker. Concentrated nitric acid (20ml) and perchloric acid $(10 \mathrm{ml})$ were added to contents of the beaker, and then evaporated to near dryness on a hot plate at a temperature of $80 \pm 5^{\circ} \mathrm{C}$ in a fume chamber until a colorless liquid was obtained. Each digested prawn sample was analyzed for metal concentration using an Atomic Absorption Spectrophotometer Unican 969, 1996 model. The analytical procedure was checked using reference material (DORM 1, Institute of Environmental Chemistry and NRC Canada). Concentration levels of metals (Fe, $\mathrm{Mg}$ and $\mathrm{Zn}$ ) were expressed in $\mathrm{mg} / 100 \mathrm{~g}$ dry weight according to the method of APHA.

\section{Analysis of Data}

Data were computed using SPSS version 20 and analyzed using one-way ANOVA at five percent level of significance. Mean values between seasons was analyzed using the T-test method.

\section{RESULTS}

\section{Water Physico-Chemical and Proximate Parameters of Macrobrachium vollenhovenii from Badagry creek}

As shown in Table 1, the mean physico-chemical parameters recorded in Badagry creek are: temperature $\left(27.80 \pm 2.40^{\circ} \mathrm{C}\right), \mathrm{pH}(6.92 \pm 0.40)$, salinity $(4.15 \pm 1.30 \mathrm{ppt})$, dissolved oxygen $(5.90 \pm 0.50 \mathrm{mg} / \mathrm{L})$, total alkalinity $(50.60 \pm 8.80 \mathrm{mg} / \mathrm{L})$ and total hardness $(133.10 \pm 11.60 \mathrm{mg} / \mathrm{L})$.

The monthly values of proximate parameters of Macrobrachium vollenhovenii from Badagry Creek are presented in Table 2. Aside carbohydrate contents which showed no monthly significant differences $(\mathrm{p}=.05)$, other proximate parameters of $M$. 
vollenhovenii had significant monthly variation. The respective maximum protein and lipid contents $(53.17 \pm 0.35 \%, 10.24 \pm 0.16 \%)$ in $M$. vollenhovenii from Badagry Creek were obtained in July while the least $(42.00 \pm 0.18 \%$, 3.00 $\pm 0.08 \%)$ were recorded in the month of March and February respectively. On the other hand, the peak ash $(24.29 \pm 0.16 \%)$, crude fibre $(14.90 \pm 0.13 \%)$ and moisture $(36.00 \pm 0.50 \%)$ contents were recorded in August, February and March respectively. However, the least ash $(11.00 \pm 0.26 \%)$, crude fibre $(3.80 \pm 0.05 \%)$ and moisture $(3.70 \pm 0.20 \%)$ were obtained in February, March and July respectively.

Table 1: Some Physico-Chemical Parameters of Badagry Creek

\begin{tabular}{ll}
\hline Parameters & Mean Values \\
\hline Temperature $\left({ }^{0} \mathbf{C}\right)$ & $27.80 \pm 2.40$ \\
Dissolved Oxygen (mg/L) & $5.90 \pm 0.50$ \\
pH & $6.92 \pm 0.40$ \\
Salinity (ppt) & $4.15 \pm 1.30$ \\
Total Alkalinity (mg/L) & $50.60 \pm 8.80$ \\
Total Hardness (mg/L) & $133.10 \pm 11.60$ \\
\hline
\end{tabular}

Table 2: Monthly Variations in Proximate Content of Macrobrachium vollenhovenii from Badagry Creek

\begin{tabular}{lllll}
\hline Parameters & July & August & February & March \\
\hline Protein (\%) & $53.17 \pm 0.35^{\mathrm{a}}$ & $51.20 \pm 0.29^{\mathrm{ab}}$ & $44.00 \pm 0.43^{\mathrm{b}}$ & $42.00 \pm 0.18^{\mathrm{bb}}$ \\
Moisture (\%) & $3.70 \pm 0.20^{\mathrm{a}}$ & $4.46 \pm 0.14^{\mathrm{a}}$ & $26.50 \pm 0.65^{\mathrm{ab}}$ & $36.00 \pm 0.50^{\mathrm{b}}$ \\
Ash (\%) & $22.49 \pm 0.60^{\mathrm{a}}$ & $24.29 \pm 0.16^{\mathrm{a}}$ & $11.00 \pm 0.26^{\mathrm{ab}}$ & $13.00 \pm 0.18^{\mathrm{b}}$ \\
Lipids (\%) & $10.24 \pm 0.16^{\mathrm{a}}$ & $9.06 \pm 0.05^{\mathrm{a}}$ & $3.00 \pm 0.08^{\mathrm{b}}$ & $4.00 \pm 0.10^{\mathrm{b}}$ \\
Carbohydrate(\%) & $1.61 \pm 0.05^{\mathrm{a}}$ & $1.50 \pm 0.02^{\mathrm{a}}$ & $1.50 \pm 0.08^{\mathrm{a}}$ & $1.20 \pm 0.04^{\mathrm{a}}$ \\
Crude Fibre (\%) & $8.80 \pm 0.26^{\mathrm{a}}$ & $9.50 \pm 0.13^{\mathrm{a}}$ & $14.90 \pm 0.13^{\mathrm{ab}}$ & $3.80 \pm 0.05^{\mathrm{b}}$
\end{tabular}

Mean \pm SD with same superscript in the row are not significantly different $(\mathrm{p}=.05)$

The respective rainy and dry seasonal variations for protein $(52.18 \pm 1.11$, $43.13 \pm 1.13)$, moisture $(4.08 \pm 0.44,31.25 \pm 5.23)$, ash $(23.39 \pm 1.06,12.00 \pm 1.11)$, lipids $(9.65 \pm 0.65,3.50 \pm 0.55)$, carbohydrate $(1.58 \pm 0.07,1.35 \pm 0.17)$ and crude fibre $(9.15 \pm 0.42$, 9.35 \pm 6.08 ) are presented in Fig. 2. The proximate parameters (except carbohydrate and crude fibre) showed significant $(\mathrm{p}=.05)$ seasonal variation. 


\section{Monthly and Seasonal Variation of Trace Metals Concentrations in M. vollenhovenii from Badagry Creek}

The monthly concentrations of the trace metals in M. vollenhovenii from Badagry creek are presented in Table 3 while Fig. 3 showed the seasonal variation of the metals in the shellfish. Among the metals examined in $M$. vollenhovenii, only magnesium $(\mathrm{Mg})$ contents showed significant $(\mathrm{p}=.05)$ difference. The highest value for $\mathrm{Mg}(21.04 \pm 0.08$ $\mathrm{mg} / 100 \mathrm{~g}$ ) was recorded in February while the least $(18.02 \pm 0.15 \mathrm{mg} / 100 \mathrm{~g})$ was obtained in July. Similarly, significant seasonal variation was recorded for $\mathrm{Mg}$, with the higher value $(20.00 \pm 1.02 \mathrm{mg} / 100 \mathrm{~g})$ obtained in rainy season and the lower value $(18.00 \pm 1.10 \mathrm{mg} / 100 \mathrm{~g})$ during dry season. Other metals recorded in rainy and dry seasons respectively were: $\mathrm{Fe}-(3.03 \pm 0.40 \mathrm{mg} / 100 \mathrm{~g}$ and $2.59 \pm 0.39 \mathrm{mg} / 100 \mathrm{~g})$ and $\mathrm{Zn}$ $(5.10 \pm 0.64 \mathrm{mg} / 100 \mathrm{~g}$ and $5.16 \pm 0.27 \mathrm{mg} / 100 \mathrm{~g})$.

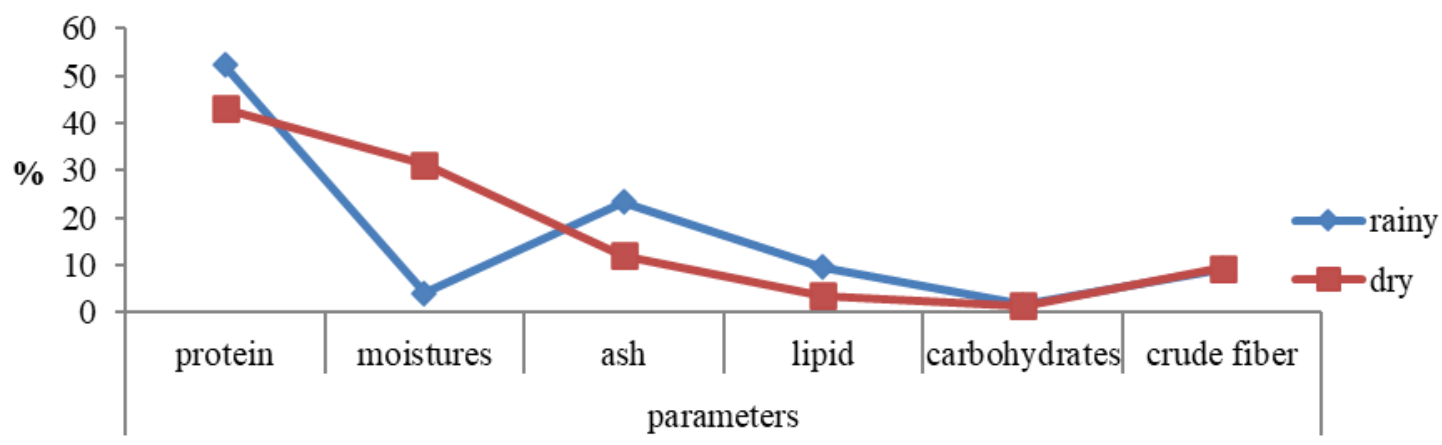

Fig. 2: Seasonal Variation in Proximate Composition of Macrobrachium vollenhovenii from Badagry Creek

Table 3: Monthly Variation of Trace Metals Concentrations in M. vollenhovenii from Badagry Creek

\begin{tabular}{lllll}
\hline Metals & July & August & February & March \\
\hline Zn (mg/100g) & $5.20 \pm 0.10^{\mathrm{a}}$ & $5.13 \pm 0.41^{\mathrm{a}}$ & $5.31 \pm 0.77^{\mathrm{a}}$ & $4.90 \pm 0.56^{\mathrm{a}}$ \\
$\mathbf{M g}(\mathbf{m g} / \mathbf{1 0 0 g})$ & $18.02 \pm 0.15^{\mathrm{a}}$ & $19.72 \pm 0.92^{\mathrm{b}}$ & $21.04 \pm 0.08^{\mathrm{ab}}$ & $19.27 \pm 0.51^{\mathrm{b}}$ \\
$\mathbf{F e}(\mathbf{m g} / \mathbf{1 0 0 g})$ & $2.58 \pm 0.07^{\mathrm{a}}$ & $2.61 \pm 0.61^{\mathrm{a}}$ & $2.95 \pm 0.06^{\mathrm{a}}$ & $3.12 \pm 0.62^{\mathrm{a}}$ \\
\hline
\end{tabular}

Mean \pm SD with same superscript in the row are not significantly different at $(\mathrm{p}=.05)$ 


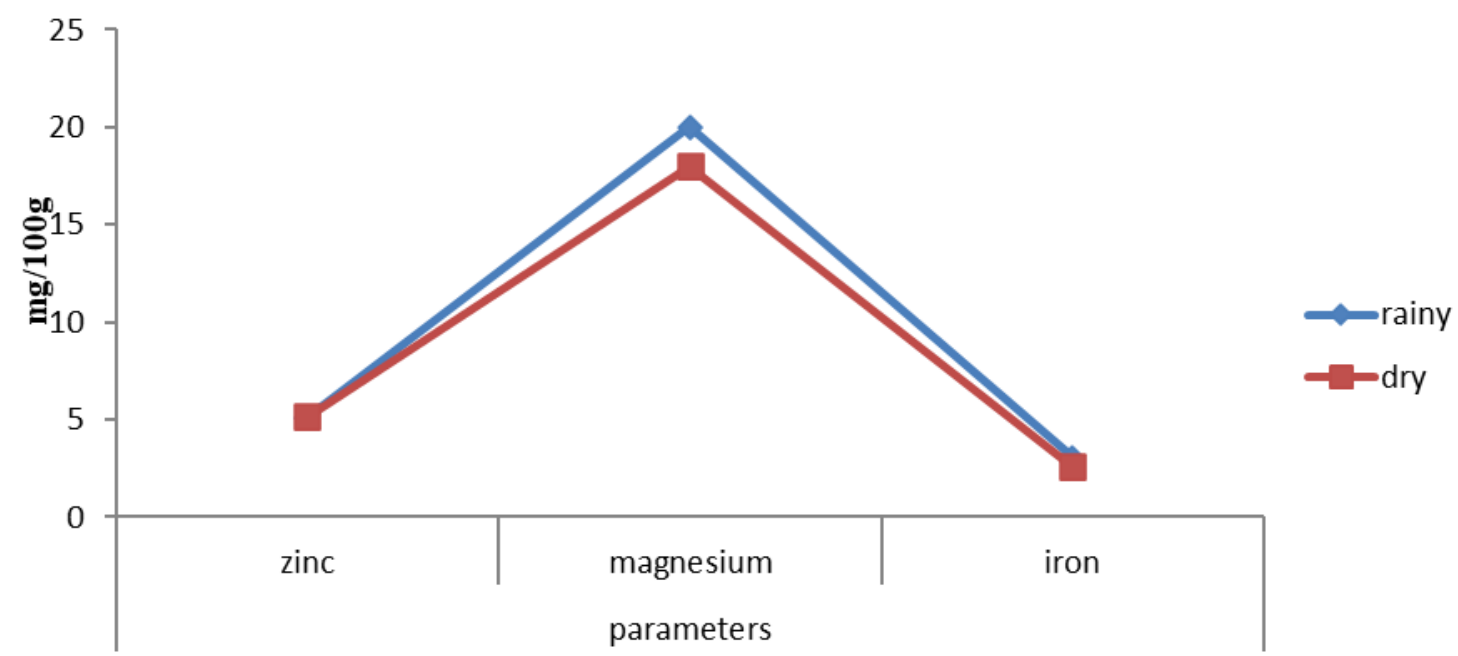

Fig. 3: Seasonal Variation of Trace Metals in Macrobrachium vollenhovenii from Badagry Creek.

\section{DISCUSSION}

\section{Physico-Chemical and Proximate Parameters}

The dissolved oxygen, temperature, salinity and $\mathrm{pH}$ recorded in this study were within the standard range of dissolved oxygen $(>5.0 \mathrm{mg} / \mathrm{L})$, temperature $\left(<40^{\circ} \mathrm{C}\right)$, salinity $(>0.5)$ for brackish water and $\mathrm{pH}$ of 6.5 - 9.5 (FEPA, 2007). However, the concentrations of total alkalinity and total hardness were above the values of $45 \mathrm{mg} / \mathrm{L}$ (total alkalinity) and $100 \mathrm{mg} / \mathrm{L}$ (total hardness) recommended by FEPA (2007). The favourable parameters such as dissolved oxygen (DO), $\mathrm{pH}$, and temperature could be the basis for the successful fisheries in Badagry creek. However, high hardness recorded in this study is an indication of poor water quality. All water parameters recorded in this study are lower than that obtained in Asejire Lake (Jenyo-Oni and Oladele, 2016) and Tomaro creek (Nwankwo et al., 2013).

Most proximate parameters of the Macrobrachium vollenhovenii had significant monthly variation and this could be attributed to the quality of food available to the fish during different months. The high content of protein recorded in this study indicated that $M$. vollenhovenii is a good source of amino acids. High protein content in $M$. vollenhovenii can also be attributed to its omnivorous feeding habit. The protein content recorded in this study agrees with the results of Ehigiator and Nwangwu (2011) who reported crude protein levels of $53.38 \pm 4.38 \%$ and $56.5 \pm 3.82 \%$ for $M$. vollenhovenii and M. macrobrachion respectively. Asiru and Fafioye (2018) also reported mean protein value of $46.06 \pm 0.38$ for $M$. vollenhovenii from River Osun. 
Lipids in shell fish are rich source of essential and polyunsaturated fatty acids. Lipid levels in shell fish are reported to be dependent on the source and proportion of lipids in the diet, moulting cycle and the season (Gopakumar and Rajendranathan, 1975). In this study, the lipid content which varied from $3.00 \pm 0.08 \%$ to $10.24 \pm 0.16 \%$ indicates high fat content. The high value recorded for fat in $M$. vollenhovenii implies that this prawn can serve as a source of non-visible oil in any diet (Ehigator and Nwangwu, 2011). Lipid contents in this study was similar to that reported for $M$. vollenhovenii by Ehigator and Nwangwu, $2011(11.00 \pm 0.00 \%)$ and Asiru and Fafioye, 2018 $(12.98 \pm 1.48 \%$ ), but higher than that reported in Penaeus notialis (Diler and Ata 2003 ), Penaeus semisulcatus and Metapenaeus monoceros (Yanar and Çelik, 2005). Ehigator and Oterai (2012) reported that exoskeleton and appendages of $M$. vollenhovenii had low fat content and thus propounded that the greater the protein and lipid content, the higher the energy density inherent. Generally, along with proteins, lipids act as major food reserves and are subjected to periodic fluctuations influenced by environmental variables such as temperature (Nagabhushanan and Farooqui, 1982).

The proximate percentage composition of moisture and ash are good indicators of physiological condition of an organism. The significant moisture difference observed in February and March compared to other months could be due to the difference in feed availability. Knowledge of the moisture content of substances serves as a useful index of their qualities and susceptibilities to decomposition and even infections. Moisture content obtained in this study for both Rainy and Dry seasons was significantly lower than that reported by Sriket et al. (2007) for Penaeus monodon (black tiger shrimp) and Penaeus vannamei (white shrimp).

The ash contents in this study were $23.39 \pm 1.06$ (Rainy season) and $12.00 \pm 1.11$ (Dry season). Although these values were lower than that reported earlier for $M$. vollenhovenii from Ologe lagoon (Anethekai et al., 2007), the values were, however, similar to those reported for M. vollenhovenii by Ehigator and Nwangwu (2011) and Asiru and Fafioye(2018). The ash content of any sample is an indication of the richness, in various elements, of the sample. The high ash content in freshwater prawns is as a result of the high level of chitin in the exoskeleton of shellfishes. This high level of ash has been observed in the exoskeleton of shrimps found in Lagos Lagoon (Adeyeye, 2002). A level of ash much higher than expected may indicate the presence of other materials that may contain higher inorganic materials than the substance in question, while a lower level may indicate dilution or contamination of the food with substances having lower inorganic level. Ehigator and Oterai (2012) reported that the ash content of periwinkle ranged between $10 \%$ and $10.55 \%$, with the exoskeleton and the shell of the periwinkle (Tympanotonus fuscatus) having higher values of ash than other parts of the body.

In this study, there was no significant monthly or seasonal variation in carbohydrate contents for $M$. vollenhovenii. This trend could be attributed to the fact that carbohydrate contribute a meager percentage to the biochemical make-up when compared to protein and ash contents. The carbohydrate content in this study were $1.58 \pm 0.07$ (Rain) and 1.35 \pm 0.17 (Dry), and these were lower than the value reported for carbohydrate 
content of exoskeleton from $M$. vollenhovenii (Ehigator and Nwangwu, 2012). However, the value of carbohydrate in this study was similar to that recorded for $P$. indicus (Ravichandran et al., 2009). Various factors such as gonad development in addition to starvation, feeding, rest, exercise and other physiological states are said to affect the carbohydrate level in shrimps (Ehigator and Nwangwu, 2012).

Crude fibre is a physiological and nutritional concept relating to those carbohydrate components of foods that are not digested in the small intestine. Crude fibre content observed in this study showed no significant difference between July and August but significant difference between February and other month. Also, value in March was significantly different from other months. The crude fibre values was quite low in dry season and this agreed with the findings of Ravichandran et al. (2009) who recorded a range of crude fibre level of $8.2 \%$ (flesh) and $8.7 \%$ (shell) in Penaeus indicus.

Among the metals examined in $M$. vollenhovenii, only magnesium $(\mathrm{Mg})$ contents showed significant monthly and seasonal variations. This could imply that $\mathrm{Mg}$ is readily more abundant in Badagry creek. Magnesium is an activator of the enzyme system which functions in the metabolism of carbohydrates to produce energy and magnesium in conjunction with phosphorus, calcium, manganese, vitamin A, C and D, chlorine and protein involved in bone formation but calcium is the principal contributor. Shanker $\boldsymbol{e} t$ al. (2011) recorded magnesium concentrations of 1.07-2.56 in Perna viridis. Omoigberale and Ikponmwosa-Eweka (2010) reported magnesium levels of (0.391.12) in palaemonid shrimp (Macrobrachium vollenhovenii) in Ovia river, while Ehigiator and Oterai (2012) recorded magnesium values ranging from (1.16-1.24) in Tympanotonus fuscatus from Ovia river. One of the major reasons for the high values of heavy metals recorded in $M$. vollenhovenii might be due to the presence of exoskeleton in M. vollenhovenii, as the exoskeleton is able to accumulate heavy metals. Also, this higher metal load in $M$. vollenhovenii than fin fishes might be due to limited mobility of $M$. vollenhovenii compared to the fin fishes (Jimoh et al., 2011). This causes the prawns to accumulate more metals than the fin fishes, which makes the prawns better aquatic biomonitor than the fin-fishes which swim away as quickly as possible from polluted environment. The high heavy metals values might also be due to the feeding habit of $M$. vollenhovenii as prawns have been reported to be benthic feeders (Anetekhai et al., 2007) and this tends to expose the prawns to lots of metal load in detritus and sediments, which act as sink for the non-biodegradable heavy metals (Kumolu- Johnson et al., 2010).

Zinc and $\mathrm{Fe}$ are essential elements and play important roles in growth, cell metabolism and survival of most animals including crustaceans. The mean concentrations of Fe and $\mathrm{Zn}$ recorded during rainy and dry seasons were lower than the range of values of $\mathrm{Fe}$ and $\mathrm{Zn}$ reported by Anetekhai et al. (2007) in M. vollenhovenii from Ologe Lagoon, Lagos, Nigeria. The differences in the metal values might be due to greater metal load in Ologe Lagoon because of its proximity to Agbara Industrial Estate, which discharges its effluents into the Lagoon (Kusemiju et al., 2001). Shanker et al. (2011) recorded Iron concentrations of (2.68-5.66) in Perna viridis of the Vellar Estuary while Levent et al. (2013) reported zinc levels of range (18-36) in Crangon crangon from the 
Southern Black Sea (Turkey) and Banjo et al. (2010) reported Zinc level of (5.60: g/g) in M. vollenhovenii from different markets in southwest, Nigeria. The zinc values obtained in the present study were similar to that recorded for Podophthalmus vigil (Soundarapandian et al., 2013) and that recorded in Penaeus indicus (Ravichandran et al., 2009).

All the values of metals obtained in this study are lower than the maximum allowable limits in food fish set by the World Health Organization (2008) as: $(\mathrm{Fe}=$ $10 \mathrm{mg} / 100 \mathrm{~g} ; \mathrm{Zn}=1-7.5 \mathrm{mg} / 100 \mathrm{~g} ; \mathrm{Mg}=5-50 \mathrm{mg} / 100 \mathrm{~g}$ ) as well as that of Federal Environmental Protection Agency (FEPA, 2007) which were: $(\mathrm{Fe}=10 \mathrm{mg} / 100 \mathrm{~g}$ and $\mathrm{Zn}=$ $7.5 \mathrm{mg} / 100 \mathrm{~g}$ ). The implication of this is that $M$. vollenhovenii from Badagry creek can be recommended for human consumption. These low concentrations of trace metals in Badagry creek might be due to minimal use of agro-chemicals and reduced industrial activities (which are a major source of metals in the aquatic environment) around Badagry creek.

\section{CONCLUSION}

In conclusion, the consumption of shellfishes and finfishes has long been a major factor in the economy and nutrition of coastal population. This study provided valuable information on proximate composition of $M$. vollenhovenii from Badagry creek, in order to take necessary precautions in processing from a manufacturer point of view. Also, to help the consumers in choosing shellfish based on their nutritional values with providing an update to our general food composition database. The study revealed that $M$. vollenhovenii from Badagry creek is a good source of nutrients (carbohydrate, protein, lipids, ash, crude fibre and moisture). The species also contain significant safe proportion of zinc, iron and magnesium that are important for metabolic processes and maintenance of health. However, fishing from Badagry creek should be done responsibly on an ongoing basis because the quality of aquatic environment can easily influence the physiological and nutritional compositions of this shellfish

\section{REFERENCES}

Adeyeye, E.I. (2002): Determination of the chemical composition of the nutritionally valuable parts of the male and female crab, Sudananautes africanus. International Journal of Food Science and Nutrition, 53: 189-196.

Anetekhai, M.A.; Akinoriola, G.A.; Aderinola, O.J. and Akintola, S.L. (2007). Trace metals concentration in Macrobrachium vollenhovenii from Ologe Lagoon, Lagos, Nigeria. Journal of Afrotropical Zoology, Special Issue (Proceedings of the Third International Conference on African Fish and Fisheries, Cotonou, Benin, 10-14 November, 2003), pp. 25-29.

American Public Health Association, APHA (1992). Standard Methods for the Examination of Water and Wastewater. 20th End., American Public Health Association, Washington, DC., USA., Pages: 1220.

Association of Analytical Chemists, AOAC (2000). Official Method of the Association of Analytical Chemists $17^{\text {th }}$ Edn; AOAC, Washington, DC; USA; 447pp. 
Asiru, R.A. and Fafioye, O.O. (2018). Proximate composition of the giant river prawn, Macrobrachium vollenhovenii from River Osun, southwestern Nigeria. Journal of Fisheries and Livestock Production, 6: 285. doi: 10.4172/2332-2608.1000285

Asuquo F.E. and Udoh J.P. (2002): Pattern of total hydrocarbon, copper and iron in some fish for Cross River Estuary, Nigeria. West African Journal of Applied Ecology, 3: 91-97.

Banjo, A.D.; Lawal, A.O.; Fasunwon, B.T. and Alimi, G.O. (2010). Alkali and Heavy Metal contaminants of Some Selected Edible Arthropods in South Western Nigeria. American-Eurasian Journal of Toxicological Sciences, 2(1): 25-29.

Boyd, C.E. (1981). Water quality in warm water fish ponds. Alabama Agricultural Experimental Station, Auburn University, Alabama, pp: 358.

Diler, A. and Ata, S. (2003): Microbiological and chemical quality and meat yield of Penaeus semisulcatus (De Haan 1884) caught from the Antalya region. Turkish Journal Veterinary and Animal Science, 27: 497-503.

Dong, F.M. (2001): The nutritional value of shellfish. A Washington Sea Grant Programme publication, pp:8.

Ehigiator, F.A.R. and Nwangwu, I.M. (2011): Comparative Studies of the Proximate Composition of Three Body Parts of Two Freshwater Prawns Species from Ovia River, Edo State, Nigeria. Australian Journal of Basic and Applied Sciences, 5(12): 2899-2903,

Ehigiator, F.A.R. and Oterai, E.A. (2012): Chemical composition and amino acid profile of a Caridean prawn (Macrobrachium vollenhovenii) from Ovia River and tropical periwinkle (Tympanotonus fuscatus) from Benin River, Edo State, Nigeria. International Journal of Research and Reviews in Science, IJRRAS 11(1): 162-167.

Federal Environmental Protection Agency, FEPA (2007). National Guidelines and Standard for Water Quality in Nigeria. FEPA, Lagos, Nigeria, pp: 114.

Gopakumar, K. and Rajendranathan, N.M. (1975). Lipid composition of five species of Indian prawns. Journal of Science, Food and Agriculture, 26: 319-325.

Jenyo-Oni, A. and Oladele, A.H. (2016). Heavy metals assessment in water, sediments and selected aquatic organisms in Lake Asejire, Nigeria. European Scientific Journal, 12: 339-351.

Jimoh, A.A.; Clarke, E.O. and Godwin, A.O. (2019). Seasonal and spatial variations in physico-chemical parameters of water and proximate composition of Macrobrachium macrobrachion from Ologe Lagoon and Badagry Creek, Lagos, Nigeria. Global Journal of Fisheries Science, 1(3): 32-40. doi.org/10.31248/GJFS2019.012

Jimoh, A.A.; Clarke, E.O.; Ndimele, P.E.; Kumolu-Johnson, C.A. and Adebayo, F.A. (2011). Concentrations of heavy metals in Macrobrachium vollenhovenii (Herklots, 1857) from Epe Lagoon, Lagos, Nigeria. Research Journal of Environment and Earth Science, 3(3): 197-202.

Jimoh, A.A. and Anetekhai, M.A. (2004): Food, feeding habits and sex ratio in the African river prawn, Macrobrachium vollenhovenii (Herklots, 1857) from Ologe Lagoon, Lagos, Nigeria. Southwest Nigeria. Journal of Research and Review in Science, 3(1): 61-64. 
Kumolu-Johnson, C.A.; Ndimele P.E.; Akintola S.L. and Jibuike, C.C. (2010): Copper, zinc and iron concentrations in water, sediment and Cynothrissa mento (Regan, 1917) from Ologe Lagoon, Nigeria: a preliminary survey. African Journal of Aquatic Science, 35(1): 87-94.

Kusemiju, K.; Fadiya A.A.; Aderinola O.J. and Akintola, S.L. (2001): Comparative analysis of heavy metals in water, sediments and tissues of Lumbricus violaceus from Agbara and Iba streams, Nigeria. Journal of Research and Review in Science, 2: 114-117.

Lawal-Are, A.O. and. Kusemiju, K. (2000): Size composition, growth pattern and feeding habits of the blue crab, Callinectes amnicola (DeRocheburne) in the Badagry lagoon, Nigeria. Journal of Scientific Research and Development, 4: 117-126.

Levent, B.; Fatih, Ş.; Murat, S.; Funda, Ü.; Oylum, G.B. and Hasan, C.Ö. (2013). Heavy metals in edible tissues of the brown shrimp-Crangon crangon (Linnaeus, 1758) from the Southern Black Sea (Turkey). Journal of Black Sea/Mediterranean Environment, 19(1): 70-81.

Nagabhushanam, R. and Mane, V.H. (1978). Seasonal variation in the biochemical composition of Perna viridis at Ratnagirii on the West Coast of India. Journal of Hydrobiologia, 57(3): 69-72.

Nagabhushanan, R. and Farooqui, V.M. (1982). Mobilization of protein, glycogen, and lipid during ovarian maturation in mature crabs Scylla serrate. Indian Journal of Marine Science, 11: 184-189.

Ndimele, P.E. and Jimoh A.A. (2011): Water hyacinth (Eichhornia crassipes (Mart.) Solms.) in phytoremediation of heavy metal polluted water of Ologe Lagoon, Lagos, Nigeria. Research Journal of Environmental Science, 5: 424-433.

Nwankwo, D. I.; Adesalu, T.A.; Amako, C. C.; Akagha, S. C. and Keyede, J. D. (2013). Temporal variations in water chemistry and chlorophyll- $a$ at the Tomaro creek Lagos, Nigeria. Journal of Ecology and Natural Environment, 5 (7): 145151.

Omoigberale, M.O. and Ikponwosa-Eweka, O. (2010). Evaluation of heavy metals of the palaemonid shrimp, Macrobrachium vollenhovenii in Ovia River, Nigeria. Biosci. Res. Commun. 22(5): 247- 258.

Powell, C.B. (1982): Fresh and brackish water shrimps of economic importance in the Niger Delta. Proceedings of 2nd Annual Conference of the Fisheries Society of Nigeria, Calabar, Cross-River State, Nigeria. $22^{\text {nd }}-24^{\text {th }}$ January, 1982.

Ravichandran, S.; Rameshkumar, G. and Rosario, P.A. (2009): Biochemical composition of shell and flesh of the Indian white shrimp Penaeus indicus. American-Eurasian Journal of Scientific Research, 4(3): 191-194.

Shanker A.; Saradha, A.; Nazar R. and BadhulHaq, M.R. (2011): Proximate composition and bioaccumulation of metals in some finfishes and shellfishes of Vellar Estuary (South east coast of India). European Journal of Experimental Biology, 2011, 1 (2):47-55

Siva-Reddy, K.V.; Babu, K.R. and Raju, M.R. (2013). Proximate composition of the prawn, Macrobrachium rosenbergii, from Andrha Pradesh coast, India. International Journal of Current Science, 8: 16-20. 
Soundarapandian, P.; Ravichandran, S. and Varadharajan, D. (2013) Biochemical Composition of edible Crab, Podophthalmus vigil (Fabricius). Journal of Marine Science, Research and Development, 3:119. doi: 10.4172/2155-9910.1000119

Sriket, P.; Benjakul S.; Visessanguan W. and Kijroongrojana, K. (2007): Comparative studies on chemical composition and thermal properties of black tiger shrimp (Penaeus monodon) and white shrimp (Penaeus vannamei) meats. Food Chemistry, 103: 1199-1207.

World Health Organization, WHO (2008): Permissible Limits of Heavy Metals in Food; World Health Organization, Geneva, Switzerland.

Yanar, Y. and Celik, M. (2005): Seasonal amino acid profiles and mineral contents of green tiger shrimp (Penaeus semisulcatus, De Haan, 1844) and speckled shrimp (Metapenaeus monocrecos, Fabricus, 1789) from the Eastern Mediterranean Sea. Food Chemistry, 94: 33-36. 